\title{
Resisting temptation: Is compulsive buying an expression of personality deficits?
}

Laurence Claes ${ }^{1,2}, \mathrm{PhD}$ and Astrid Müller ${ }^{3}, \mathrm{MD}, \mathrm{PhD}$

${ }^{1}$ KU Leuven, Faculty of Psychology and Education Sciences, Leuven, Belgium

${ }^{2}$ University of Antwerp, Faculty of Medicine and Health Sciences (CAPRI), Antwerp, Belgium

${ }^{3}$ Hannover Medical School, Department of Psychosomatic Medicine and Psychotherapy, Hannover, Germany

\section{Corresponding author:}

Laurence Claes

KU Leuven - Faculty of Psychology and Educational Sciences

Tiensestraat 102, box 3720

3000 Leuven

Belgium

Phone: +32-16-32.61.33

Fax: $+32-16-32.59 .16$

E-mail: Laurence.claes@kuleuven.be

Keywords: compulsive buying; temperament; personality; impulsivity; Big Five 


\begin{abstract}
Purpose of review: We summarized studies focusing on the associations between compulsive buying and temperament/personality traits in community and clinical samples published between 2010 and 2016.

Recent findings: We found significant associations between compulsive buying (CB) and high levels of Behavioral Activation System (BAS) reactivity, Novelty Seeking, and Positive Urgency (promotion focus), as well as high levels of Neuroticism, Emotional Instability, and Negative Urgency (prevention focus). Finally, the results showed negative associations between $\mathrm{CB}$ and lack of Effortful Control, Self-Control, Perseverance and Premeditation.
\end{abstract}

Summary: CB seems to be driven by positive reinforcement and negative reinforcement as well as a breakdown in self-regulation. Longitudinal studies need to investigate the development of $\mathrm{CB}$ throughout time, and experimental studies need to examine whether individuals with CB suffer from a general vs. a cue-specific breakdown in self-regulation. Psychotherapy needs to focus on the training of self-control as well as the development of behavioral alternatives to regulate emotions. 


\section{Introduction}

$\mathrm{CB}$ can be defined as a preoccupation with buying, by frequent buying episodes, or urges to buy that are experienced as irresistible [1]. The buying episodes are accompanied by pleasure (positive reinforcement) and relief (negative reinforcement), but followed by remorse and guilt due to psychological, social, occupational and financial problems related to maladaptive spending [2]. The prevalence of $\mathrm{CB}$ in adults is approximately $5 \%$ and younger people are more prone to develop CB [3]. Patients with CB suffer from both, Axis I (e.g., anxiety, depression, substance abuse, binge eating) and Axis II (e.g., avoidant, obsessive-compulsive and borderline personality disorders (PDs)) comorbid disorders [2]. Previous research showed that $90 \%$ of patients with CB showed at least one life-time Axis I diagnosis and that $60 \%$ reported at least one Axis II diagnosis [4]. Recently, several authors reported significantly positive associations between CB and the Cluster B borderline $(r=.42, p$ $<.001)$ and narcissistic $(r=.31, p<.001)[5,6]$ personality disorder features. Among many other vulnerability factors (such as materialistic value endorsement, decision-making difficulties, low selfesteem, depression, etc.) [2], individual differences in personality functioning are considered as possible precursors of $\mathrm{CB}$ in both community and clinical samples [7].

The aim of the present chapter is to offer an overview of studies which focused on the associations between CB and different dimensional temperament/personality models between 2010 and 2016. Findings concerning the associations between CB and temperament/personality traits published before 2010 can be found in a review by Claes and Müller [8]. In what follows, we discuss the associations between $\mathrm{CB}$ and (a) the reactive and regulative temperamental model of Gray and Rothbart [9, 10], (b) the five personality dimensions of the Big Five Model [11], (c) the temperament and character dimensions of the Psychosocial Theory [12], and (d) the Impulsivity dimensions of Barratt [13] and the UPPS-P model [14] (see Table 1).

\section{$\mathrm{CB}$ and reactive and regulative temperament}

First, we investigated CB from a temperamental point of view. Rotbhart, Ahadi and Evans [15] define temperament as individual differences in reactivity and self-regulation. "Reactivity refers to the excitability, responsivity, or arousability of the behavioral and physiological systems of the organism, whereas self-regulation refers to neural and behavioral processes functioning to modulate this underlying reactivity" [15, p. 123]. Reactive temperament (bottom-up) can be conceptualized in terms of two separate neurobiological systems: the Behavioral Inhibition System (BIS) and the Behavioral Activation System (BAS) [9]. The BIS is sensitive to stimuli that signal punishment and omission/termination of reward, and is involved in avoidance behavior. The BIS is related to negative affectivity and personality traits like Neuroticism and Harm Avoidance. The BAS is sensitive to stimuli that signal reward and relief from punishment, and is involved in approach behavior. The BAS is related to positive affectivity and personality traits like Extraversion and Sensation Seeking [16]. 
The reactivity of the BISBAS systems can be assessed by means of the BISBAS scales [17] or the Sensitivity to Punishment and Sensitivity to Reward Scale (SPSRQ) [18]. Besides reactive temperament, also self-regulation (top-down) can play a role in human behavior. Self-regulation is synonymously used with self-control [19] or effortful control [10] and is related to personality traits like Conscientiousness, Persistence and Self-Directedness. Self-regulation is often assessed by means of the Effortful Control Scale of the Adult Temperament Questionnaire measuring Attentional Control, Activation Control and Inhibitory Control [20] or the Self-Control Scale [21]. Studies that investigated the associations between $\mathrm{CB}$ and reactive and regulative temperament in community and clinical samples (see Table 1) showed that $\mathrm{CB}$ is significantly related with high levels of BAS reactivity/reward sensitivity and with low levels of effortful control/self-regulation, particularly in females [16,22-26]. In males, on the contrary, CB seemed to be related to high levels of BIS reactivity and low levels of effortful control [27].

\section{Compulsive buying and the Big Five personality traits}

The Five Factor Model (FFM) organizes personality traits into five higher-order factors being Neuroticism (emotional instability), Extraversion (energetic, outgoing), Openness (creative, openminded), Agreeableness (friendly/compassionate) and Conscientiousness (well-organized, efficient), and 30 lower-order facets (six for each factor) [11]. To assess the Big Five personality traits and their facets, the most commonly used questionnaires are the NEO-Five Factor Inventory (NEO-FFI, 60 items) and the NEO-Personality Inventory-Revised (NEO-PI-R, 240 items) [11, 28]. However, also shorter questionnaires were developed to assess the Big Five traits such as the Big Five Mini Marker Scale [29] and the mini-International Personality Item Pool (mini-IPIP) [30]. Studies which investigated the association between $\mathrm{CB}$ and the Big Five personality traits in community and clinical samples (most often in females), showed that CB is significantly positive related with Neuroticism and negative with Agreeableness and Conscientiousness [31-34]. Only studies, performed in Pakistan [35, 36], did not confirm these findings and showed positive associations between CB and all Big Five personality traits.

\section{$\mathrm{CB}$ and the character and temperament dimensions of the Psychosocial Theory of Cloninger}

The Psychosocial Theory of Cloninger [12] describes four character dimensions, being Harm Avoidance (anxious, doubtful), Novelty Seeking (kick-seeking), Reward Dependence (sensitive to social reward) and Persistence (perseverance in spite of fatigue/frustration) and three temperament dimensions, being Self-Directedness (conscientiousness), Cooperativeness (agreeableness), and SelfTranscendence (experiencing rituals ideas). The Temperament and Character Inventory-Revised (TCIR) [37] is the most frequently used questionnaire to assess the dimensions of the Psychosocial Theory. Three of the four studies which investigated the associations between CB and the temperament and 
character dimensions, showed that $\mathrm{CB}$ is significantly positive related with Novelty Seeking (i.e., kick-seeking) in patients with CB, bipolar disorder and substance use disorder [38-40].

\section{CB and the impulsivity dimensions of Barratt and Cyders (UPPS-P model)}

Impulsivity can be defined as the tendency to act impulsively or without prior reflection or thought. The Barratt Impulsiveness Scale-11 item version (BIS-11) [13, 41] is often used to assess the impulsivity trait. The BIS-11 has three subscales, being attentional impulsivity (not paying attention), motor impulsivity (acting without thinking) and non-planning impulsivity (opposite of planning carefully). Many studies have investigated the associations between CB and BIS-11 (sub)scales and showed systematically significantly positive associations between CB and (attentional, motor and nonplanning) impulsiveness in both community and clinical samples [38-40, 42, 43].

Finally, several studies which investigated the association between CB and impulsivity made use of the UPPS-P model (the five impulsivity traits of the FFM) [14, 44]. The UPPS-P model consists of the following five dimensions: Negative Urgency (act impulsive in the presence of negative affect), Lack of Perseverance (easily stop an action in progress), Lack of Premeditation (act without thinking), Sensation Seeking and Positive Urgency (act impulsive in the presence of positive affect). The UPPS$\mathrm{P}$ model can be assessed by means of the UPPS-P Impulsivity Scale [44]. Both studies which investigated the associations between $\mathrm{CB}$ and negative/positive urgency showed significantly positive associations between $\mathrm{CB}$ and negative/positive urgency [45, 46]. Also the two other UPPS-P dimensions, lack of perseveration and lack of premeditation showed positive associations with $\mathrm{CB}$ [46].

\section{Conclusions}

Based on the findings of this review, we can conclude that CB is significantly related to both reactive (bottom-up) and regulative (top down) temperament features. First, CB is significantly related to Neuroticism, Behavioral Inhibition System Reactivity (in males), Affective Lability and Negative Urgency which can be related to the negative reinforcement function of $\mathrm{CB}$. $\mathrm{CB}$ can thus be considered as a mean to decrease negative affect (prevention focus) [7], which was confirmed in a study using ecological momentary assessment (EMA) [47]. Secondly, CB is also related to Behavioral Activation System reactivity, Stimulus Seeking, Novelty Seeking and Positive Urgency, which can be related to the positive reinforcement function of CB. CB can be considered as a mean to gain pleasure, a 'kick', and a feeling of being reward (i.e. promotion focus) [7]. In sum, from a reactive temperament

point of view; CB can be viewed as a way to gain pleasure/reward (promotion focus) and to avoid negative affect or punishment (prevention focus). Longitudinal research is urgently needed to address the question of whether the functionality of $\mathrm{CB}$ changes throughout time (e.g., from positive to negative reinforcement). Does CB start as a mean to acquire positive affect, and later on (when CB becomes addictive) as a mean to decrease negative affect? Or do there exist different types of 
individuals with $\mathrm{CB}$ of whom some use repetitive shopping/buying as a mean to gain reward; and others use it to avoid negative affect? Finally, almost all studies clearly show that CB is related to deficits in top-down or effortful control, self-control, and self-directedness [7]. Future studies should investigate whether individuals with $\mathrm{CB}$ show a general deficit in self-regulation, or whether their effortful control is particular vulnerable in the presence of "favorite buying items" [48]. Given that many patients with $\mathrm{CB}$ have completely shifted to online shopping, it is of growing interest to investigate if the aforementioned pattern differs between traditional CB (i.e. buying in bricks-andmortar-based stores) and CB via the internet.

Based on these findings, it is easily to understand that CBT seems to be the treatment of choice for patients with $\mathrm{CB}$ given that CBT offers stimulus control techniques, exposure and response prevention which help to train effortful control, as well as the development of alternative behaviors (emotion regulation strategies) to gain reward and to reduce negative affect which is often the functionality of CB [2]. 


\section{References}

Papers of particular interest, published recently, have been highlighted as:

** Of major importance

1. McElroy SL, Keck PE, Pope HG, Smith JM, Strakwoski SM. Compulsive buying: A report of 20 cases. Journal of Clinical Psychiatry 1994;55:242-8.

2.** Müller A, Mitchell JE, de Zwaan, M. Compulsive Buying. Am J Addiction 2015; 24:132-7. This manuscript contains the state-of-the-art of the compulsive buying disorder.

3. Maraz A, Griffiths MD, Demetrovics Z. The prevalence of compulsive buying: a meta-analysis. Addiction, 2016;111:408-19. doi:10.1016/j.addbeh.2016.04.003.

4. Mueller A, Mitchell JE, Black DW, Crosby RD, Berg K, de Zwaan M. Latent profile analysis and comorbidity in a sample of individuals with compulsive buying disorder. Psychiat Res; 2010;178:348-53. doi:10.1016/j.psychres.2010.04.021.

5. Sansone RA, Chang J, Jewell B, Sellbom M, Bidwell M. Compulsive buying and borderline personality symptomatology. J Pers Disord 2013;27:260-68.

6. Harnish RJ, Bridges KR. Compulsive Buying: The role of irrational beliefs, materialism, and narcissism. J Rat-Emo Cognitive-Behav Ther 2015;33:1-16. doi:10.1007/s10942-014-0197-0.

7. Verplanken B, Sato A. The Psychology of impulsive buying: An integrative self-regulation approach. J Consum Policy 2011;34:197-210. doi:10.1007/s10603-011-9158-5.

8.** Claes L, Mueller A. Personality and Compulsive Buying Disorder In: Mueller A, Mitchell JE, editors. Compulsive buying: clinical foundations and treatment. New York/London: Routledge Taylor \& Francis Group; 2010. This book chapter reviewed the literature concerning the association between personality and compulsive buying disorder till 2010. Compulsive buying is driven by neuroticism (anxiety, negative affectivity) and the absence of self-regulation, effortful control or conscientiousness.

9. Gray JA. The neuropsychology of anxiety: An inquiry into the functions of the septalhippocampal system. Oxford: Oxford University Press; 1982.

10. Rothbart MK. Temperament and development. In: Kohnstamm GA, Bates JE, Rothbart MK, editors. Temperament in childhood. Oxford: John Wiley; 1989.

11. Costa PT, McCrae RR. NEO-PI-R: The revised NEO personality inventory. Odessa, FL: Psychological Assessment Resources; 1992. 
12. Cloninger CR, Svrakic DM, Przybeck TR. A psychobiological model of temperament and character. Arch Gen Psychiat 1993;50:975-90.

13. Barratt ES. Impulsiveness substrates: arousal and information processing In: Spence JT, Izard CE, editors. Motivation, emotion, and personality. North Holland: Elsevier Science Publishers; 1985.

14. Cyders MA, Smith GT, Spillane NS, Fischer S, Annus A, Peterson C. Integration of impulsivity and positive mood to predict risky behavior: Development and validation of a measure of positive urgency. Psychol Assessment 2007;19:107-118. doi:10.1037/1040-3590.19.1.107.

15. Rothbart MK, Ahadi SA, Evans DE. Temperament and personality: Origins and outcomes. J Pers Soc Psychol 2000;78:122-35. DOI:10.1037//0022-3514.78.1.122.

16. Claes L, Bijttebier P, Van den Eynde F, Mitchell JE, Faber R, de Zwaan M, et al. Emotional reactivity and self-regulation in relation to compulsive buying Pers Indiv Diff 2010;49:526-30. doi:10.1016/j.paid.2010.05.020.

17. Carver CS, White TL. Behavioural inhibition, behavioural activation, and affective responses to impending reward and punishment: The BIS/BAS scales. J Pers Soc Psychol 1994;67:319-33.

18. Torrubia R, Avila C, Molt OJ, Caseras X. The sensitivity to punishment and sensitivity to reward questionnaire (SPSRQ) as a measure of Grays anxiety and impulsivity dimensions. Pers Indiv Diff 2001;31:837-862.

19. Baumeister RF, Heatherton TF, Tice DM. Losing control: how and why people fail at selfregulation. San Diego, CA: Academic Press; 1994.

20. Evans DE, Rothbart MK. Developing a model for adult temperament. J Res Pers 2007;41:86888. doi:10.1016/j.jrp.2006.11.002.

21. Tangney JP, Baumeister RF, Boone AL. High self-control predicts good adjustment, less pathology, better grades, and interpersonal success. J Pers 2004;72:271-324. doi:10.1111/j.0022-3506.2004.00263.x.

22. Achtziger A, Hubert M, Kenning P, Raab G, Reisch, L. Debt out of control: The links between self-control, compulsive buying, and real debts. J Econ Psychol 2015;49:141-9. doi:10.1016/j.joep.2015.04.003.

23. Claes L, Bijttebier P, Mitchell JE, de Zwaan M, Mueller A. The relationship between compulsive buying, eating disorder symptoms, and temperament in a sample of female students. Compr Psychiat 2011;52:50-5. doi:10.1016/j.comppsych.2010.05.003. 
24. Claes L, Müller A, Norré J, Van Assche L, Wonderlich S, Mitchell JE. The relationship among compulsive buying, compulsive internet use and temperament in a sample of female patients with eating disorders. Eur Eat Disord Rev 2012;20:126-31. doi:10.1002/erv.1136.

25. Müller A, Claes L, Georgiadou E, Möllenkamp M, Voth EM, Faber RJ, et al. Is compulsive buying related to materialism, depression, or temperament? Findings from a sample of treatment-seeking patients with CB. Psychiat Res 2014;216:103-7. doi:10.1016/j.psychres.2014.01.012.

26. Voth EM, Claes L, Georgiadou E, Selle J, Trotzke P, Brand M, et al. Reactive and regulative temperament in patients with compulsive buying and non-clinical controls measured by selfreport and performance-based tasks. Compr Psychiat 2014;55:1505-12. doi:10.1016/j.comppsych.2014.05.011.

27. Mueller A, Claes L, Mitchell JE, Faber RJ, Fischer J, de Zwaan M. Does compulsive buying differ between male and female students? Pers Indiv Diff 2011;50:1300-12. doi:10.1016/j.paid.2011.02.026.

28. McCrae RR, Costa PT. A contemplated revision of the NEO Five-Factor Inventory. Pers Indiv Diff 2004;36:587-96. doi:10.1016/S0191-8869(03)00118-1.

29. Saucier G. Mini-markers: A brief version of Goldberg's unipolar big-five markers. J Pers Assess 1994;63:506-16.

30. Donnellan MB, Oswald FL, Baird BM, Lucas, RE. The mini-IPIP: tiny-yet-effective measures of the Big Five factors of personality. Psychol Assessment 2006;18:192-203. doi:10.1037/1040-3590.18.2.192.

31. Andreassen CS, Griffiths MD, Gjertsen SR, Krossbakken E, Kvam S, Pallesen S. The relationships between behavioral addictions and the five-factor model of personality. J Behav Addict 2013;2:90-9. doi:10.1556/JBA.2.2013.003.

32. Donnelly G, Ksendzova M, Howell RT. Sadness, identity, and plastic in over-shopping: The interplay of materialism, poor credit management, and emotional buying motives in predicting compulsive buying. J Econ Psychol 2013;39:113-25. doi:10.1016/j.joep.2013.07.006.

33. Otero-Lopez JM, Villardefrancos E. Five-Factor Model personality traits, materialism, and excessive buying: A mediational analysis. Pers Indiv Diff 2013; 54:767-72. doi:10.1016/j.paid.2012.12.013.

34. Otero-Lopez JM, Villardefrancos-Pol E. Compulsive buying and the Five-Factor Model of personality: A facet analysis. Pers Indiv Diff 2013;55:585-90. http://dx.doi.org/10.1016/j.paid.2013.05.005. 
35. Cheema F, Phanwar I, Zia S, Rasool M. Exploring the personality traits as cause of compulsive buying behavior. J Bus Strat 2014;8:19-29.

36. Shahjehan A, Qureshi JA, Zeb F, Saifullah K. The effect of personality on impulsive and compulsive buying behaviors. African Journal of Business Management 2012;6:2187-94.

37. Cloninger CR. The temperament and character inventory-revised. St Louis, MO: Center for Psychobiology of Personality; 1999.

38. Black DW, Shaw M, McCormick B, Bayless JD, Allen J. Neuropsychological performance, impulsivity, ADHD symptoms, and novelty seeking in compulsive buying disorder. Psychiat Res 2012;200:581-7. doi:10.1016/j.psychres.2012.06.003.

39. Di Nicola M, Tedeschi D, Mazza M, Martinotti G, Harnic D, Catalano V, et al. Behavioural addictions in bipolar disorder patients: Role of impulsivity and personality dimensions. J Affect Disorders 2010;125:82-8. doi:10.1016/j.jad.2009.12.016.

40. Di Nicola M, Tedeschi D, De Risio L, Pettorruso M, Martinotti G, Ruggeri F, et al. Cooccurrence of alcohol use disorder an behavioral addictions: relevance of impulsivity and craving. Drug and Alcohol Dependence 2015;148:118-25. http://dx.doi.org/10.1016/j.drugalcdep.2014.12.028.

41. Patton JH, Stanford MS, Barratt ES. Factor structure of the Barratt Impulsiveness Scale. J Clin Psychol 1995;51:768-74.

42. Maraz A, Urban R, Demetrovics Z. Borderline personality disorder and compulsive buying: A multivariate etiological model. Addict Behav 2016;60:117-23. doi:10.1016/j.addbeh.2016.04.003.

43. Mueller A, Claes L, Mitchell JE, Wonderlich SA, Crosby RD, de Zwaan, M. Personality prototypes in individuals with compulsive buying based on the Big Five Model. Beh Res Ther 2010;48:930-5. doi:10.1016/j.brat.2010.05.020.

44. Lynam D, Smith GT, Cyders MA, Fischer S, Whiteside, SA. The UPPS-P: A multidimensional measure of risk for impulsive behavior. Unpublished technical report; 2007.

45. Rose P, Segrist DJ. Negative and positive urgency may both be risk factors for compulsive buying. J Behav Addict 2014; 3:128-32. doi:10.1556/JBA.3.2014.011.

46. Williams AD, Grisham JR. Impulsivity, emotion regulation, and mindful attentional focus in compulsive buying. Cognitive Ther Res 2012;36:451-57. doi:10.1007/s10608-011-9384-9. 
47. Mueller A, Mitchell JE, Crosby RD, Cao L, Claes L, de Zwaan, M. Mood states preceding and following compulsive buying episodes: An ecological momentary assessment study. Psychiat Res 2012;200:575-80. doi.org/10.1016/j.psychres.2012.04.015.

48. Trotzke P, Stracke K, Müller A, Brand M. Pathological buying online as a specific form of internet addiction: A model-based experimental investigation. PlosONE 2015, doi:10.1371/journalpone0140296.

49. Davenport K, Houston JE, Griffiths MD. Excessive eating and compulsive buying behaviours in women: An empirical pilot study examining reward sensitivity, anxiety, impulsivity, self-esteem and social desirability. Int J Ment Health Addiction 2012;10:474-89. doi:10.1007/s11469-0119332-7.

50. Granero R, Fernandez-Aranda F, Bano M, Steward T, Mestre-Bach G, del Pino-Gutierrez A, et al. Compulsive buying disorder clustering based on sex, age, onset and personality traits. Compr Psychiat 2016;68:1-10. doi:10.1016/j.comppsych.2016.03.003.

51. Faber RJ, O’Guinn TC. A clinical screener for compulsive buying. J Consum Res 1992;19:45969.

52. Edwards EA. Development of a new scale for measuring compulsive buying behavior Financial. Counseling and Planning 1993;4:67-84.

53. Raab G, Neuner M, Reisch LA, Scherhorn G. SKSK - Screeningverfahren zur Erhebung von kompensatorischem und süchtigem Kaufverhalten. Göttingen/Bern/Vienna: Hogrefe; 2005.

54. Ridgway NM, Kukar-Kinney M, Monroe KB. An expanded conceptualization and a new measure of compulsive buying. J Consum Res 2008;35:622-39. doi:10.1086/591108.

55. Valence G, d'Astous A, Fortier L. Compulsive buying: Concept and measurement. J Consum Policy 1988;11:419-33.

56. Livesley WJ, Jackson DN. Manual for the Dimensional Assessment of Personality Pathology Basic Questionnaire (DAPP-BQ). Port Huron: Sigma Press; 2002. 
Table 1. Overview of studies investigating the associations between $\mathrm{CB} /$ impulsive buying and temperament/personality dimensions

\begin{tabular}{|c|c|c|c|c|}
\hline $\begin{array}{l}\text { Authors } \\
\text { Country }\end{array}$ & $\begin{array}{l}\text { Sample, gender distribution }(\%), \\
\text { mean age } \pm \text { SD (years), mean baseline } \\
\text { BMI } \pm \text { SD (year) }\end{array}$ & Instruments & Analysis & Results \\
\hline \multicolumn{5}{|c|}{ Reactive and Regulative Temperament (Gray, 1982; Rothbart, 1989) } \\
\hline $\begin{array}{l}\text { Claes et al. (2010) [16] } \\
\text { Belgium }\end{array}$ & $\begin{array}{l}130 \text { undergraduate psychology students } \\
100 \% \text { females } \\
\text { Age: } 22.3 \text { (3.6) years }\end{array}$ & $\begin{array}{l}\text { BISBAS } \\
\text { Scales } \\
\text { ATQ-SF-EC + } \\
\text { SCS } \\
\text { CBS }\end{array}$ & Correlations & $\begin{array}{l}\text { CB correlated significantly positive with BAS-Fun Seeking } \\
(r=.33), \quad \text { BAS-Drive }(r=.31), \quad \text { BAS-Reward } \\
\text { Responsiveness }(r=.37) \text { and negative with Effortful } \\
\text { Control (combination of SCS+EC) }(r=.-37)\end{array}$ \\
\hline $\begin{array}{l}\text { Claes et al. (2011) [23] } \\
\text { Belgium + Germany }\end{array}$ & $\begin{array}{l}292 \text { Belgian and German undergraduate } \\
\text { students } \\
72.3 \% \text { females } \\
\text { Age: } 22.56(33.9) \text { years }\end{array}$ & $\begin{array}{l}\text { BISBAS } \\
\text { Scales } \\
\text { ATQ-SF-EC } \\
\text { CBS }\end{array}$ & Correlations & $\begin{array}{l}\text { CB correlated significantly positive with BAS-Total }(r= \\
.30) \text { BAS-Fun Seeking }(r=.33) \text { BAS-Reward } \\
\text { Responsiveness }(r=.25) \text { and negative with Effortful } \\
\text { Control-Total }(r=-.39) \text {, EC-Inhibitory Control }(r=-.30) \text {, } \\
\text { EC-Activation Control }(r=-.34) \text { and EC-Attentional } \\
\text { Control }(r=-.27)\end{array}$ \\
\hline $\begin{array}{l}\text { Mueller et al. (2011) [27] } \\
\text { Belgium + Germany }\end{array}$ & $\begin{array}{l}10 \text { Belgian and German undergraduate } \\
\text { students } \\
70 \% \text { females } \\
\text { Age: } 22.9(3.7) \text { years }\end{array}$ & $\begin{array}{l}\text { BISBAS } \\
\text { Scales } \\
\text { ATQ-SF-EC } \\
\text { CBS } \\
\end{array}$ & Correlations & $\begin{array}{l}\text { In male students, CB correlated significantly positive with } \\
\text { BIS }(r=.20) \text { and negative with EC }(r=-.32) \\
\text { In female students, CB correlated significantly positive with } \\
\text { BAS }(r=.22) \text { and negative with EC }(r=-.35)\end{array}$ \\
\hline $\begin{array}{l}\text { Davenport et al. (2012) } \\
\text { [49] } \\
\text { UK }\end{array}$ & $\begin{array}{l}134 \text { students at a university in the East } \\
\text { Midlands of the UK } \\
100 \% \text { females } \\
\text { Age: majority between } 18-24 \text { years }\end{array}$ & $\begin{array}{l}\text { SR } \\
\text { BIS-11 } \\
\text { CBS }\end{array}$ & Correlations & $\begin{array}{l}\text { CB correlated significantly positive with Sensitivity to } \\
\text { Reward }(r=.41) \text { and Impulsivity }(r=.46)\end{array}$ \\
\hline $\begin{array}{l}\text { Achtziger et al. (2015) } \\
\text { [22] } \\
\text { Germany }\end{array}$ & $\begin{array}{l}\text { Representative sample of the German } \\
\text { population }(\mathrm{n}=946) \\
55.39 \% \text { females } \\
\text { Age: } 48.96(17.54) \text { years }\end{array}$ & $\begin{array}{l}\text { SCS } \\
\text { GABS }\end{array}$ & Correlations & $\begin{array}{l}\text { CB was significantly negative related with self-control }(r= \\
-.41)\end{array}$ \\
\hline $\begin{array}{l}\text { Claes et al. (2012) [24] } \\
\text { Belgium }\end{array}$ & $\begin{array}{l}60 \text { patients with an eating disorder } \\
100 \% \text { females } \\
\text { Age: } 27.82(9.76) \text { years }\end{array}$ & $\begin{array}{l}\text { BISBAS } \\
\text { Scales } \\
\text { ATQ-SF-EC } \\
\text { DAPP-BQ } \\
\text { CBS } \\
\end{array}$ & Correlations & $\begin{array}{l}\text { CB correlated significantly positive with DAPP-Affective } \\
\text { Lability }(r=.29) \text {, DAPP-Stimulus Seeking }(r=.30) \text {, and } \\
\text { negative with Effortful Control-Total }(r=-.43) \text {, EC- } \\
\text { Inhibitory Control }(r=-.41) \text {, EC-Activation Control }(r=- \\
\text { 43) }\end{array}$ \\
\hline $\begin{array}{l}\text { Müller et al. (2014) [25] } \\
\text { Germany }\end{array}$ & $\begin{array}{l}\text { 102 patients with CB } \\
77.5 \% \text { females } \\
\text { Age: } 39.2(11.7) \text { years }\end{array}$ & $\begin{array}{l}\text { BISBAS } \\
\text { Scales } \\
\text { ATQ-SF-EC } \\
\text { CBS } \\
\end{array}$ & Correlations & $\begin{array}{l}\text { In patients with } \mathrm{CB}, \mathrm{CB} \text { correlated significantly positive } \\
\text { with BAS }(r=.28)\end{array}$ \\
\hline
\end{tabular}




\begin{tabular}{|c|c|c|c|c|}
\hline & $\begin{array}{l}28 \text { matched healthy controls } \\
80.6 \% \text { females }(\mathrm{CB}) \\
82.1 \% \text { females }(\mathrm{HC}) \\
\text { Age }_{\mathrm{CB}}: 40.65(11.26) \\
\text { Age }_{\mathrm{HC}}: 39.07(10.29)\end{array}$ & $\begin{array}{l}\text { Scales } \\
\text { ATQ-SF-EC } \\
\text { CBS }\end{array}$ & & $\begin{array}{l}\text { EC compared to healthy controls After controlling for } \\
\text { depression, only the difference on BAS reactivity remained } \\
\text { significant }\end{array}$ \\
\hline \multicolumn{5}{|c|}{ Big Five Model (Costa \& McCrae, 1992) } \\
\hline $\begin{array}{l}\text { Shahjehan et al. (2012) } \\
\text { [36] } \\
\text { Pakistan }\end{array}$ & $\begin{array}{l}640 \text { students of a public sector } \\
\text { university of Pakistan } \\
42.8 \% \text { females } \\
\text { Age: between } 20 y-30 y(95.5 \%)\end{array}$ & $\begin{array}{l}\text { Big Five Mini } \\
\text { Markers } \\
\text { Compulsive } \\
\text { Buying } \\
\text { (Valence et al, } \\
\text { 1988) }\end{array}$ & Correlations & $\begin{array}{l}\text { CB was positively related to Neuroticism }(r=.22) \text {, } \\
\text { Extraversion }(r=.22) \text {, Openness }(r=.17) \text {, Agreeableness }(r \\
=.18) \text {, and Conscientiousness }(r=.19)\end{array}$ \\
\hline $\begin{array}{l}\text { Donnely et al. (2013) [32] } \\
\text { USA }\end{array}$ & $\begin{array}{l}1077 \text { students (sample } 1) \\
74 \% \text { females } \\
\text { Age: } 24.23 \text { (9.71) years } \\
650 \text { students (sample } 2) \\
67.7 \% \text { females } \\
\text { Age: } 30.27(12.91) \text { years }\end{array}$ & $\begin{array}{l}\text { Big Five Mini } \\
\text { Markers } \\
\text { CBS }\end{array}$ & Correlations & $\begin{array}{l}\text { In sample } 1 / 2, \mathrm{CB} \text { correlated significantly positive with } \\
\text { Neuroticism }(r=.25 / .19) \text { and negative with Agreeableness } \\
(r=-22 /-12), \text { Conscientiousness }(r=-.19-/-.23) \text { and } \\
\text { Openness }(r=-.11 / \mathrm{ns})\end{array}$ \\
\hline $\begin{array}{l}\text { Otero-Lopez et al. } \\
\text { (2013a) [33] } \\
\text { Spain }\end{array}$ & $\begin{array}{l}667 \text { adults general Galician population } \\
100 \% \text { females } \\
\text { Age: } 38.4(6.1)\end{array}$ & $\begin{array}{l}\text { NEO-PI-R } \\
\text { GABS }\end{array}$ & Correlations & $\begin{array}{l}\text { CB was significantly positive related to Neuroticism }(r= \\
.33) \text { and negatively related to Agreeableness }(r=-.17) \text { and } \\
\text { Conscientiousness }(r=-.27)\end{array}$ \\
\hline $\begin{array}{l}\text { Otero-Lopez et al. } \\
(2013 b)[34] \\
\text { Spain }\end{array}$ & $\begin{array}{l}1365 \text { adults general Galician population } \\
51.6 \% \text { females } \\
\text { Age: } 39.7(13.9)\end{array}$ & $\begin{array}{l}\text { NEO-PI-R } \\
\text { GABS }\end{array}$ & MANCOVA & $\begin{array}{l}\text { The high CB group scored significantly higher on } \\
\text { Neuroticism (facets) and lower on Conscientiousness } \\
\text { (facets) and Agreeableness (facets) compared to the low and } \\
\text { moderate CB groups The high CB group scored also } \\
\text { significantly higher on the Extraversion facet excitement- } \\
\text { seeking and lower on the Extraversion facets Positive } \\
\text { Emotions and Assertiveness }\end{array}$ \\
\hline $\begin{array}{l}\text { Andreassen et al. (2013) } \\
\text { [31] } \\
\text { Norway }\end{array}$ & $\begin{array}{l}218 \text { undergraduate students } \\
792 \% \text { females } \\
\text { Age: } 20.6(3.0)\end{array}$ & $\begin{array}{l}\text { NEO-FFI-R } \\
\text { CBS }\end{array}$ & Correlations & $\begin{array}{l}\text { CB correlated significantly positive with Neuroticism }(r= \\
.17) \text { and negative with Agreeableness }(r=-.24) \text { and } \\
\text { Conscientiousness }(r=-.28)\end{array}$ \\
\hline $\begin{array}{l}\text { Cheema et al. (2014) [35] } \\
\text { Pakistan }\end{array}$ & $\begin{array}{l}400 \text { individuals of the city of Karachi } \\
\text { (Pakistan) } \\
50 \% \text { females } \\
\text { Age: }>18 \text { years }\end{array}$ & $\begin{array}{l}\text { Mini-IPIP } \\
\text { RCBS }\end{array}$ & Correlations & $\begin{array}{l}\text { CB was significantly positive related to Neuroticism }(r= \\
.96) \text {, Extraversion }(r=.83) \text {, Intellect }(r=96) \text {, } \\
\text { Agreeableness }(r=.88) \text {, and Conscientiousness }(r=.96)\end{array}$ \\
\hline Mueller et al. (2010) [43] & $\begin{array}{l}68 \text { patients with } \mathrm{CB} \\
85 \% \text { females } \\
\text { Age: } 40.6(10.6) \text { years }\end{array}$ & $\begin{array}{l}\text { NEO-FFI } \\
\text { BIS-11 } \\
\text { CBS }\end{array}$ & $\begin{array}{l}\text { K-means cluster } \\
\text { analysis }\end{array}$ & $\begin{array}{l}\text { Cluster I of CB patients was characterized by positive z- } \\
\text { scores on each of the Big Five personality traits; whereas } \\
\text { Cluster II was characterized by a positive z-score on } \\
\text { Neuroticism and negative z-scores on Extraversion, }\end{array}$ \\
\hline
\end{tabular}


Openness, Agreeableness and Conscientiousness CB patients of Cluster II scored significantly higher on the Barratt Impulsiveness Scale than CB patients of Cluster I

\begin{tabular}{|c|c|c|c|c|}
\hline & & & & \\
\hline \multicolumn{5}{|c|}{ Psychosocial model of Cloninger (1999) } \\
\hline Black et al. (2012) [38] & 26 persons with $\mathrm{CB}$ & TCI & ANOVA & CB scored significantly higher on TCI-Novelty Seeking and \\
\hline \multirow[t]{5}{*}{ USA } & 32 healthy controls $(\mathrm{HC})$ & BIS-11 & & on BIS-Total, BIS-Attentional, BIS-Motor, BIS-Non- \\
\hline & $88 \%$ females $\mathrm{CB}$ & CBS & & Planning Impulsivity compared to healthy controls \\
\hline & $84 \%$ females controls & & & \\
\hline & Age $_{\mathrm{CB}}: 36.6(15.7)$ & & & \\
\hline & Age $_{\mathrm{HC}}: 39.7(14.8)$ & & & \\
\hline \multirow{3}{*}{$\begin{array}{l}\text { Di Nicola et al. (2010) } \\
\text { [39] } \\
\text { Italy }\end{array}$} & 158 patients with Bipolar Disorder & TCI-R & \multirow[t]{3}{*}{ Correlations } & CB correlated significantly positive with TCI-Novelty \\
\hline & $59 \%$ females & BIS-11 & & Seeking $(r=.30)$, Self-Transcendence $(r=.25)$ and BIS-11 \\
\hline & Age $_{\mathrm{BD}}: 48.7(12.7)$ years & CBS & & $\begin{array}{l}\text { Impulsivity }(r=.35) \text {; and negative with TCI-Self- } \\
\text { Directedness }(r=-.28) \text { and Cooperativeness }(r=-.30)\end{array}$ \\
\hline Di Nicola et al. (2015) & 95 Alcohol Use Disorder patients & TCI-R & \multirow[t]{6}{*}{ Correlations } & In AUD patients, $\mathrm{CB}$ correlated significantly positive with \\
\hline$[40]$ & 140 healthy controls & BIS-11 & & TCI-Novelty Seeking $(r=.33)$ and BIS-11 Impulsivity $(r=$ \\
\hline \multirow[t]{4}{*}{ Italy } & $40 \%$ females (AUD) & CBS & & \\
\hline & $39.3 \%$ females $(\mathrm{HC})$ & & & In healthy controls, $\mathrm{CB}$ correlated significantly positive \\
\hline & Age $_{\mathrm{AUD}}: 44.1(9.5)$ years & & & with TCI-Novelty Seeking $(r=.38)$ and BIS-11 Impulsivity \\
\hline & Age $_{\mathrm{HC}}: 42.4(12.2)$ years & & & $(r=.30)$ \\
\hline Granero et al. (2016) [50] & 110 patients with $\mathrm{CB}$ disorder & TCI-R & \multirow{6}{*}{$\begin{array}{l}\text { Agglomerative } \\
\text { hierarchical } \\
\text { clustering method }\end{array}$} & The 'male CB' reported the lowest levels of TCI-Reward \\
\hline Spain & $67.3 \%$ females & & & Dependence The 'female low-dysfunctional CB' scored the \\
\hline & Cluster 1: male CB $(n=32)$ & & & lowest on TCI-Harm Avoidance and the highest on TCI- \\
\hline & $\begin{array}{l}\text { Cluster 2: female low dysfunctional } \\
(\mathrm{n}=32)\end{array}$ & & & $\begin{array}{l}\text { Persistence, Self-Directedness, and Cooperativeness The } \\
\text { 'female high dysfunctional CB' reported the highest levels }\end{array}$ \\
\hline & $\begin{array}{l}\text { Cluster 3: female high dysfunctional } \\
(\mathrm{n}=46)\end{array}$ & & & $\begin{array}{l}\text { of TCI-Harm Avoidance and the lowest levels of TCI-Self- } \\
\text { Directedness }\end{array}$ \\
\hline & Age: $432(?)$ years & & & \\
\hline \multicolumn{5}{|l|}{ Impulsivity traits } \\
\hline \multirow{2}{*}{$\begin{array}{l}\text { Maraz et al. (2016) [42] } \\
\text { Hungary }\end{array}$} & 1409 Hungarian shopping mall & BIS-11 & \multirow[t]{2}{*}{ Correlations } & CB correlated significantly positive \\
\hline & $\begin{array}{l}\text { customers } \\
63 \% \text { females } \\
\text { Age: } 31.2(12.1) \text { years }\end{array}$ & ECBS & & Impulsivity $(r=.39)$ \\
\hline \multirow{5}{*}{$\begin{array}{l}\text { Williams et al. (2012) } \\
\text { [46] }\end{array}$} & 49 compulsive buyers & UPPS-P & \multirow[t]{5}{*}{ Correlations } & \multirow{5}{*}{$\begin{array}{l}\text { CB correlated significantly positive with Positive Urgency } \\
(r=.38 / .41) \text {, Negative Urgency }(r=.50 / .55), \text { Lack of } \\
\text { Premeditation }(r=.41 / .31) \text { and Lack of Perseverance ( } r= \\
.39 / .31) \text { as measured with CBS/RCBS respectively }\end{array}$} \\
\hline & 37 healthy controls & CBS & & \\
\hline & $\%$ females: ? & RCBS & & \\
\hline & Age $_{\mathrm{CB}}: 29.02(11.24)$ years & & & \\
\hline & Age $_{\mathrm{HC}}: 25.61(7.38)$ years & & & \\
\hline
\end{tabular}




\begin{tabular}{|c|c|c|c|c|}
\hline $\begin{array}{l}\text { Rose et al. (2014) [45] } \\
\text { USA }\end{array}$ & $\begin{array}{l}514 \text { North American Adults } \\
54 \% \text { female } \\
32.97 \text { (11.18) years }\end{array}$ & $\begin{array}{l}\text { Mini-IPIP } \\
\text { UPPS-P } \\
\text { RCBS }\end{array}$ & Correlations & $\begin{array}{l}\text { CB correlated significantly positive with IPIP-Neuroticism } \\
(r=.17) \text {, Negative Urgency }(r=.43) \text { and Positive Urgency } \\
(r=.41)\end{array}$ \\
\hline
\end{tabular}

Measures of compulsive buying: CBS = Compulsive Buying Scale [51]; ECBS = Edwards Compulsive Buying Scale [52]; GABS = German Addictive Buying Scale [53]; RCBS = Richmond Compulsive Buying Scale [54]; Compulsive Buying [55]; Measures of reactive and regulative temperament: BISBAS = Behavioral Inhibition System and Behavioral Activation System Scales [17]; SPSRQ = Sensitivity to Punishment and Sensitivity to Reward Questionnaire [18]; ATQ-SF-EC = Adult Temperament Questionnaire-Short Form-Effortful Control Scale [20]; SCS = Self-Control Scale [21]; Measures of Big Five personality traits: DAPP-BQ = Dimensional Assessment of Personality Pathology-Basic Questionnaire [56]; mini-IPIP = miniInternational Personality Item Pool - Five-Factor Model [30]; Big Five Mini Markers [29]; NEO-FFI/NEO-PI-R = NEO-Five Factor Inventory (60 items)/NEO Personality Inventory-Revised (240 items) [11]; NEO-FFI-R = NEO-Five Factor Inventory-Revised [28]; Measures of Psychosocial model: TCI-R = Temperament and Character Inventory-(Revised) [12,37]; Measures of Impulsivity traits: BIS-11 = Barratt Impulsiveness Scale-11 [41]; UPPS-P = UPPS-P Impulsivity Scale [14,44]. 